\title{
Challenges of Biohydrometallurgy in the Circular Economy
}

\author{
Ellen Cristine Giese* \\ Mineral Technology Center, CETEM, Rio de Janeiro, Brazil
}

Submission: November 27, 2019; Published: December 03, 2019

*Corresponding author: Ellen Cristine Giese, Mineral Technology Center, CETEM, Rio de Janeiro, Brazil

\section{Opinion}

The sustainable management of Waste Electrical and Electronic Equipment (WEEE) is considered a challenge, given the fastest increasing stream of waste in the world. Natural resource exploitation is accelerating in the face of resource decline, while at the same time people are generating ever-growing fluxes of wastes and pollutants [1]. WEEE can be considered as a source of various metallic and nonmetallic components including critical or strategic materials for the development of new high technologies. Considering the ever-present possibility of depletion of non-renewable resources, the economic benefits of recovering valuable metals from the recycling of WEEE are potentially important in the coming decades. Metal ores stem from non-renewable resource stocks; and predictions as to how long metal world reserves will last depend mainly on economic growth, price trends and technological development [2,3]. The circular economy assumes that it is important to reuse consumer goods as well as efficiently and profitably extract valuable inputs from discarded materials such as electronic waste while mitigating environmental impacts over decades for those same wastes $[4,5]$. In developed and developing countries, the correlation between WEEE generation and its GDP is clear [6] as well as this correlation was also observed for South American countries [7]. Circular supply chains cannot circulate 100\% of resources and hence new resource inputs from the natural environment will remain necessary. Moreover, a transition towards a circular economy requires innovative technologies for WEEE recovery and recycling practices to be sustainably managed.

Biohydrometallurgy emerges as a green technology allied with the circular economy $[5,8]$. This bioprocess has already been shown to be a relevant option for the bioprocessing of both lowgrade ores and traditional mining waste. Biohydrometallurgy has a role to play in implementing green and responsible mining using microbial-mineral interactions that operate at a mild temperature and pressure for metal extraction. This technology seeks to minimize the use of ore beneficiation operations as comminution, concentration, e.g., reducing waste generation
$[9,10]$. Bioleaching is considered an environmentally friendly, cost-effective and promising technology for metallurgical processing, using microorganisms to solubilize and recover valuable metals from ores [10]. The use of bacteria capable of oxidizing iron and/or sulfur ores, such as acidophilic bacteria of the genera Acidithiobacillus and Leptospirillum, accelerates the oxidation rate of several mineral sulfides, mainly due to the formation of $\mathrm{Fe} 3+$ ions, which attack the mineral sulfide promoting the solubilization and consequent extraction of the metal of interest [11]. The bioleaching process for WEEE is like that of sulfide mineral ores. WEEE is alkaline and contributes to the increase of system $\mathrm{pH}$ values and, consequently, facilitates the precipitation of iron as hydroxide. The combination of iron hydroxide with ammonium, sodium, potassium and silver ions results in the formation of a Jaredite precipitate. Jaredite precipitation is a commonly used technique for the removal of iron ions in WEEE leach liquors [12]. Different industrial solid wastes are already used as secondary sources of base metals or precious metals, which are recovered using microbial leaching. Among the WEEE used as secondary sources of metal, processed by bioleaching, are batteries, printed circuit boards, TV circuit boards, brake pads and catalysts [13]. Bio hydrometallurgical processes have the potential for metal recovery and recycling by exploiting urban mines and directing them towards the circular economy. Indeed, the recovery of "green" metals or "e-tech metals" such as cobalt, tellurium, selenium, indium, gallium, lithium and rare earth elements, e.g., through a new responsible mining paradigm is a requirement for the success of the bioeconomy. Biological recovery of metals from WEEE contributes also to mitigating pollution caused by both landfilling and possible damage from the exploitation of natural mineral reserves. The combination of bioleaching and biosorption can revolutionize the interaction with the fundamental elements of nature by selectively recovering elements dispersed in the environment in the form of WEEE to concentrate them in synthetic ores for future applications without the need for toxic reagents or waste generating processes [13]. Urban biomining can be considered a solution aligned with the circular economy 
and meeting the main social, environmental, economic and technological demands. Its large-scale deployment depends on both technology and effective reverse logistics. Microbial biotechnology has attracted more attention from the global community because it is environmentally friendly technology and is often more economical than conventional technologies.

\section{Acknowledgment}

The author gratefully acknowledges the financial support for his own research cited within this article from the National Council for Scientific and Technological Development (CNPQ), Brazil.

\section{References}

1. Naraimha MPV (2020) Waste electrical and electronic equipment in India: diversity, flows, and resource recovery approaches. Handbook of Electronic Waste Management International Best Practices and Case Studies pp. 207-241.

2. Grosse F (2010) Is recycling "part of the solution"? The role of recycling in an expanding society and a world of finite resource. Sapiens 3(1): $1-7$.

3. Matinde E, Simate GS, Ndlovu S (2018) Mining and metallurgical wastes: a review of recycling and re-use practice. Journal of the Southern African Institute of Mining and Metallurgy 118(8): 824-844.

4. Velenturf APM, Purnell P, Macaskie LE, Mayes WM, Sapsford DJ (2019) A new perspective on a global circular economy. Royal society of chemistry pp. 1-22.

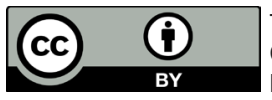

This work is licensed under Creative Commons Attribution 4.0 License DOI: 10.19080/IMST.2019.01.555569
5. Xavier LH, Giese EC, Duthie AC, Lins FAF (2019) Sustainability and the circular economy: A theoretical approach focused on e-waste urban mining. Resource Policy 101467.

6. Awasthi AK, Cucchiella F, D Adamo I, Li J, Rosa P, et al. (2018) Modelling the correlations of e-waste quantity with economic increase. Science of the Total Environment 613-614.

7. Xavier LH, Giese EC, Lins FAF (2018) Urban mining and e-waste management in South America. Proceedings SUM2018, Fourth Symposium on Urban Mining pp. 21-23.

8. Giese EC, Xavier LH, Lins FAF (2018) Urban biomineration: the future of electronic waste recycling. Brasil Mineral 385: 36-39.

9. Giese EC (2019) Evidences of EPS-iron (III) ions interactions on bioleaching process mini-review: the key to improve performance. Orbital 11: 200-204.

10. Hennebel T, Boon N, Maes S, Lenz M (2015) Biotechnologies for critical raw material recovery from primary and secondary sources: R\&D priorities and future perspectives. N Biotechnol 32(1): 121-127.

11. Baniasadi M, Vakilchap F, Bahaloo-Horeh N, Mohammad MS, Farnaud S (2019) Advances in bioleaching as a sustainable method for metal recovery from e-waste: A review. Journal of Industrial and Engineering Chemistry 76: 75-90.

12. Yazici EY, Bas AD, Deveci H (2014) Jarosite precipitation of iron from leach solutions of waste printed circuit boards (WPCBs). Proceedings of $14^{\text {th }}$ International Mineral Processing Symposium. Kuşadasi Turkey pp. 483-488.

13. Isildar A (2016) Biological versus chemical leaching of electronic waste for copper and gold recovery. Environmental Engineering.

\section{Your next submission with Juniper Publishers} will reach you the below assets

- Quality Editorial service

- Swift Peer Review

- Reprints availability

- E-prints Service

- Manuscript Podcast for convenient understanding

- Global attainment for your research

- Manuscript accessibility in different formats

( Pdf, E-pub, Full Text, Audio)

- Unceasing customer service

Track the below URL for one-step submission https://juniperpublishers.com/online-submission.php 